\title{
Argumentation and Compromise: Ireland's Selection of the Territorial Status Quo Norm
}

\author{
Markus Kornprobst
}

\begin{abstract}
How do states come to select norms? I contend that, given a number of conditions are present, states select norms in three ideal-typical stages: innovative argumentation, persuasive argumentation, and compromise. This norm selection mechanism departs from the existing literature in two important ways. First, my research elaborates on the literature on advocacy networks. I explain why agents engage in an advocacy for a normative idea in the first place; I add the epistemic dimension of reasoning to argumentation theory; and I show in detail the pathways through which persuasive argumentation links an advocated idea and alreadyestablished sets of meaning. Second, synthesizing rationalist and constructivist selection mechanisms, I contend that successful argumentation makes recalcitrant actors eager to reach a compromise with the advocates as long as this does not violate their most cherished beliefs. The Republic of Ireland's eventual selection of the territorial status quo norm in the late 1990s lends empirical evidence to this norm selection mechanism.
\end{abstract}

This study addresses two pervasive aspects of the social world: argumentation and compromise. Drawing on taken-for-granted ideas that enable us to make the world intelligible to ourselves, we make and exchange arguments to make up our minds about a particular issue and to persuade others to follow our reasoning. Some arguments convince us. We are persuaded by the line of reasoning that the argumentation contains. Other arguments, by contrast, are unconvincing. Of these unconvincing arguments, some violate our most deeply held beliefs. They upset us and we reject them categorically. Others, by contrast, do not violate our most profound beliefs. We discard them with less vigor and are prepared to compromise on our stance.

I would like to thank Michael Barnett, Steven Bernstein, Corneliu Bjola, Ian Cooper, Ted Hopf, Sandy Irvine, Jennifer Mitzen, Daniel Nexon, Nisha Shah, Janice Gross Stein, Susan Gross Solomon, Allona Sund, Vincent Pouliot, Alexander Wendt, Ruben Zaiotti, and, most of all, Emanuel Adler for very helpful comments on earlier versions of this article. I am also greatly indebted to the anonymous reviewers and the editors of $I O$ for their detailed and insightful comments. Funding for this research was generously provided by an Ontario Graduate Fellowship, the Joint Initiative for German and European Studies at the University of Toronto, and the Mershon Center at the Ohio State University.

International Organization 61, Winter 2007, pp. 69-98

(C) 2007 by The IO Foundation.

DOI: $10.1017 / \mathrm{S} 0020818307070026$ 
How do states come to select certain ideas as norms but not others? It is my contention that argumentation and compromise provide for a compelling answer to this much-debated question. ${ }^{1}$ The norm selection mechanism that I proposeone among several possible mechanisms - focuses on domestic politics. I contend that, given a set of conditions are present, states select norms in three ideal-typical stages: innovative argumentation, persuasive argumentation, and compromise. Argumentation theory helps to account for what makes actors form an advocacy (innovative argumentation), and what makes this advocacy successful (persuasive argumentation). ${ }^{2}$ Bargaining theory explains the conditions under which even those actors who remain unconvinced by an argument yield to the pressure of a successful advocacy (compromise). ${ }^{3}$

The occurrence of these three stages is contingent on a number of conditions. Much of this article is concerned with identifying these conditions. Innovative argumentation occurs if the environment in which agents are embedded changes. This change may be constituted by a revolutionary event and/or by a shifting repertoire of commonplaces on which agents draw to make the world intelligible to themselves. The revolutionary event makes it obvious to actors that the old ways of doing things have to change. The changing repertoire provides advocates with novel clues for what the new ways should look like.

Persuasive argumentation requires advocates to construct what is to their audience a compelling link between the repertoire of commonplaces and the advocated idea. In order to unpack this construction, I make two tripartite distinctions. I differentiate between three kinds of social forces that make up the repertoire of commonplaces: identity narrative, identity-constituting norms, and the episteme. The episteme- a fruitful specification of the somewhat elusive concept of worldview-is the taken-for-granted lens through which actors look at the world, including the identity narrative and its constituting norms. Moreover, similarly to Crawford, I distinguish between three modes of reasoning: abstraction (syllogism), comparison (analogy), and appropriateness (rule following). ${ }^{4}$ The two distinctions make it pos-

1. There is little debate anymore that norms matter. Yet there is a lively debate about what makes actors embrace norms. See Florini 1996; Downs, Rocke, and Barsoom 1996; Keck and Sikkink 1998; Finnemore and Sikkink 1998; Risse, Ropp, and Sikkink 1999; Bernstein 2000; Simmons 2000; Checkel 2001; Tallberg 2002; Schimmelfennig 2003; Wiener 2004; Langlois and Langlois 2004; Kelemen and Sibbitt 2004; and Dai 2005.

2. Although influenced by the normative strand of argumentation theory-especially Aristotle 1995; Cicero 1976 and 2003; and Habermas 1995a and 1995b-and the application of communicative rationality to the study of world politics in Müller 1994; and Risse 2000, I focus on its empirical strand. See Perelman and Olbrechts-Tyteca 1958; and Crawford 2002. At the center of my inquiry is the attempt to explain why an argument resonates with an audience and not how a truth-seeking discourse comes about and what its outcome is.

3. There have been a number of interesting attempts to reconcile argumentation and bargaining; see Keck 1995; and Holzinger 2001. Habermas suggests a stage model. Some stages are constituted by a particular kind of argumentation and others by a certain type of bargaining; see Habermas 1998, 207. Similarly to Habermas, I distinguish between stages but I conceptualize argumentation and bargaining differently.

4. Crawford 2002, 16-19. 
sible to map those links between the repertoire and the advocated idea that are persuasive and those that are not.

Finally, even if an advocacy is extraordinarily successful in persuading its audience, it is unlikely that it will convince everybody. Yet the power of an argument is not confined to persuasion. It may sway the unconvinced. A successful advocacy establishes a new majority view. Opposing this dominant stance is costly. This makes recalcitrant actors eager to reach a compromise with the advocates as long as this does not violate their most cherished beliefs. A compromise is impossible if the parties draw on different ideational pools for making the world intelligible to themselves. If the commonplaces used in the advocates' argumentation are outside of the repertoire of commonplaces held by recalcitrant actors, a compromise is impossible.

This theoretical framework adds complexity to existing accounts of norm selection. Yet this is warranted because of the added value that it generates. The threestage norm selection mechanism makes two sets of important contributions. First, I elaborate on the advocacy literature in several ways. Proposing a sociological theory of agency, I address the neglected question of why actors engage in an advocacy in the first place. I overcome the neglect of worldviews by including the episteme in my analysis of these linkages. And most importantly, the literature's insight that successful argumentation involves the construction of a linkage between already-established ideas and the advocated idea is not the end but merely the starting point of my inquiry. I distinguish between those links that make an argument persuasive and those that do not. Second, the literature remains bifurcated into the logic of consequences and the logic of appropriateness, although existing empirical research demonstrates that strategic calculation and persuasion matter for norm selection and compliance. ${ }^{5}$ The three-stage mechanism, however, provides a synthesis. Whereas the innovative and persuasive argumentation stages are closer to the logic of appropriateness, the compromise stage follows the logic of consequences.

I probe the plausibility of the three-stage norm selection mechanism by analyzing the process through which the Republic of Ireland came to embrace the territorial status quo norm. In the post-World War II era, European politics has gone beyond what Zacher defines as the global territorial integrity norm. ${ }^{6}$ Not only ought states not to violate the territorial integrity of another state; they ought not even claim the territory of another state. This study refers to this norm as the territorial status quo norm. A debate about the norm started in the 1950s. It became a key aspect of the Helsinki Final Act in 1975. By the end of the Cold War, Austria, West Germany, East Germany, Italy, Yugoslavia, and Greece had withdrawn their claims to territories under the sovereignty of neighboring states. Soon after attaining independence, Estonia and Latvia followed suit. Even more remarkable than

5. This dichotomy underlying much of social science research was made explicit and labeled as such by March and Olsen 1989.

6. Zacher 2001. 
that, in most of the former claimant states there is not even a debate anymore about renewing the claim. This is an indicator that they have internalized the territorial status quo norm. ${ }^{7}$

The normative change is particularly striking with regard to the Republic of Ireland. From the time the Republic gained independence, the claim to Northern Ireland was at the core of its identity. Those who broke the taboo to question the claim were vilified as traitors. The taboo prevailed longer there than in any other state in postwar Europe. In the 1990s, however, the Republic, distancing itself from earlier attempts to force unity against the will of Unionists, replaced it with the territorial status quo norm. The Republic withdrew the territorial claim in the Good Friday Agreement, and even though the Northern Irish parties have failed to implement several important provisions of the accord that had served as key incentives for Dublin to sign the agreement, the Republic has refrained from questioning the new orthodoxy that states ought not to claim territory from other states.

This article is organized into two general parts: in the theoretical part, I review the literature on norm selection and compliance, conceptualize argumentation as reasoning, and, based on this conceptualization, develop the three-stage norm selection mechanism. In the empirical part, I trace the evolution of the dominant repertoire of commonplaces of public discourse on the Irish Question, examine how agents linked the ideas they advocated to the repertoire, discuss which linkages persuaded the addressees of the advocacy and which ones did not, and analyze how the success of persuasive argumentation affected the stance of recalcitrant actors. The conclusion discusses the findings and suggests an agenda for further research.

\section{Building on the Existing Literature}

The literature on norm selection has generated a number of important insights, two of which are particularly noteworthy. First, norm selection is often connected to successful argumentation. More precisely, the advocacy literature ${ }^{8}$ echoes the central insight of argumentation theory: that advocates succeed in making a norm resonate with an audience if they manage to construct a firm link between the normative idea for which they argue and an ideational framework that is already firmly established. According to the literature, this framework is made up of identity and its constituting norms. Second, studying norms as an explanandum requires transcending the divide between the logic of appropriateness and the logic of consequences. The advocacy literature emphasizes the former over the latter. Drawing on constructivist perspectives, it conceptualizes the persuadee who comes

7. I borrow this indicator from Finnemore and Sikkink 1998, 895.

8. See Florini 1996; Keck and Sikkink 1998; Finnemore and Sikkink 1998; Risse, Ropp, and Sikkink 1999; Bernstein 2000; and Weiner 2004. 
to select a norm as homo sociologicus. The actor comes to internalize a new norm through a process that revolves around his or her identity and its (already-selected) constituting norms. The rationalist literature, by contrast, follows the logic of consequences. In this view, actors are utility-maximizing agents. They do not internalize or select a norm. They merely comply with it if this suits their exogenously given interests. ${ }^{9}$ As ontologically incompatible as these two sets of literature at first glance seem to be, they provide compelling empirical evidence for the salience of both logics of action.

In order to improve our understanding of norm selection processes, these two insights need to be developed further. The advocacy literature has shown that norm selection involves argumentation, but it falls short of specifying this argumentation process in sufficient detail. First, it neglects the issue of agency. Its focus is on what makes an advocacy stick with an audience and not with what motivates the advocates to engage in their advocacy in the first place. There is no explicit theory of agency in the advocacy literature. It is clear, for example in Finnemore and Sikkink's groundbreaking research on international advocacy networks, that advocates actually believe in the idea that they advocate (and at times calculate strategically how to best get their message across). ${ }^{10}$ But it is not clear how they come to embrace this idea.

Second, the advocacy literature overemphasizes the role of identity narratives and identity constituting norms at the expense of other ideational forces. There is a far-reaching agreement that advocates have to construct a fit between the "extant social structure" 11 and the advocated normative idea. Yet the social environment consists of more than just an identity narrative and already-selected norms. Most importantly, the literature on norm selection neglects worldviews, although there has been an agreement across the rationalist-constructivist divide for some time that worldviews matter in international relations. ${ }^{12}$ Goldstein and Keohane even argue that worldviews have a salience unmatched by other ideational forces: "Ideas have their broadest impact on human action when they take the form of worldviews." ${ }^{13}$ Norm selection, of course, is such a human action. It is somewhat startling that constructivists, including students of advocacy networks, widely share the rationalists' neglect of worldviews. Much of what is now labeled constructivism has been inspired by the work of Berger and Luckmann. The worldview ("Weltansicht") is a key ideational force for the latter. ${ }^{14}$

Third, the finding that norm selection involves fitting the advocated norm into an already-existing social environment is an important finding. But precisely

9. See Downs, Rocke, and Barsoom 1996; Simmons 2000; Langlois and Langlois 2004; Kelemen and Sibbitt 2004; and Dai 2005.

10. Finnemore and Sikkink 1998.

11. Bernstein 2000, 465.

12. See Goldstein and Keohane 1993; and Laffey and Weldes 1997.

13. Goldstein and Keohane 1993, 8.

14. See Berger and Luckmann 1966; and Luckmann 1991, 91-93. 
because it is such a key finding, it begs the question of how this process of embedding works. Such a detailed inquiry into the process through which advocates succeed or fail to embed the new into the taken-for-granted needs to elaborate on the existing research in two ways. Which already-established ideas make for a stronger fit than others? Identity narratives, for example, are a resource for successful argumentation. Yet some aspects of the narrative may make for a more powerful argumentation than others. Furthermore, which ways of linking an advocated idea to internalized ideas are persuasive and which are not? Argumentation theory, for instance, has traditionally emphasized the syllogism as a mechanism to link the old and the new. Is this the only way to construct such a fit? Is it an especially persuasive one?

Taking the two key insights of the norm selection literature as starting points for further research requires more than just elaborating on the advocacy literature. It also necessitates finding a compelling synthesis of the logic of appropriateness and the logic of consequences. There have been two important attempts to build bridges between the logics of action. First, the literature on strategic framing postulates that elites frame issues in a manner that maximizes their exogenously given interests. The framing resonates with an audience if it fits the issue into the web of meaning into which the audience is embedded. ${ }^{15}$ Second, Schimmelfennig proposes the theory of rhetorical action. Communicators, framing an issue in a way that serves their exogenously given self-interest, shame recipients into norm compliance. The recipients are rhetorically entrapped and have only two options: either they violate what they publicly stand for or they acquiesce. Since the violation of prior commitments comes at the cost of shame, they acquiesce. ${ }^{16}$

There is much to be learned from these attempts. They sketch a picture of social action that is much richer than accounts that rely solely on one logic of action. But neither of the two attempts is without its problems. The key weakness of the concept of strategic framing is the division of labor between the logics of action that it posits. It is not clear why norm entrepreneurs should be disembedded agents who operate in an ideational vacuum, whereas their audience is enmeshed in a social structure. Schimmelfennig's concept of rhetoric action is a powerful reflection on the logic of consequences through the lens of a selective interpretation of Goffman's pathbreaking work on framing. ${ }^{17}$ But it is not a synthesis of logics of action. Communicators are cost-benefit-calculating actors. Their preferences are exogenously given. And even the recipients act based on utility calculations. They acquiesce because of the costs that shaming inflicts on them.

The next section lays the conceptual groundwork for addressing these challenges by providing a richer understanding of the process of reasoning. I identify

15. See Barnett 1999; Acharya 2004; and Cortell and Davis 2005.

16. Schimmelfennig 2003.

17. As pointed out correctly in ibid., 195. Goffman's work can be read through a sociological and a microeconomic perspective. Schimmelfennig embraces the latter. See especially Goffman 1974. 
the set of ideas that enables agents to reason about normative ideas, and I classify the linkages that actors make between the former and the latter. Based on this conceptual frame, the three sections thereafter deal with the conditions giving rise to innovative argumentation, persuasive argumentation, and compromise.

\section{Reasoning About Normative Ideas}

Norm advocacy involves argumentation. Argumentation is public reasoning aimed at persuading an audience. ${ }^{18}$ Yet how do actors reason? I contend that agents pick topoi (taken-for-granted ideas in light of which the advocated idea becomes intelligible to advocates) from a broad repertoire of commonplaces that enables them to reason about normative ideas, and link these topoi to the advocated idea through three modes of reasoning: abstraction, comparison, and appropriateness.

Some ideas serve as tools that make the world intelligible to actors. They provide them with clues about how the world works. These clues are the firm ground on which they stand when they reason about the world. They do not question them, but take them for granted. ${ }^{19}$ I refer to the toolbox containing the ideas that actors use to reason about the world as the repertoire of commonplaces. Focusing on arguments about normative ideas, the advocacy literature holds that this repertoire consists of identity and its constituting norms. This study partly concurs. Identity and already-institutionalized norms are part of the repertoire of commonplaces that help us make sense of a not-yet-selected normative idea. Identity is a narrative category. Identities are constructed through communicative acts that, by connecting events of past and present, as well as desires and expectations about the future, tell stories about Self and its relationship to Other. These narratives are not objectively true or false, but they are intersubjectively plausible or implausible. ${ }^{20}$ A norm is a "standard of appropriate behavior for an actor with a given identity." 21

Identity and norms alone, however, provide an incomplete picture. Situated on a deeper layer of the ideational fabric, the episteme-a fruitful conceptualization of a worldview-delineates what is imaginable for actors and what is inconceivable. ${ }^{22}$ I define it as a set of fundamental and taken-for-granted beliefs about what is (ontological dimension) and how what is is causally connected (causal dimension); on the basis of these beliefs, social actors construct the world. Similar to scientists who, according to Kuhn, cannot but look at the world they study through

18. This definition is similar to Cicero 2003, 8. For the link between argumentation and reasoning, see also Crawford 2002, 14-16.

19. Swidler 1986.

20. See Somers 1994; and Cruz 2000.

21. Finnemore and Sikkink 1998, 891.

22. Coined by Foucault 1989a and 1989b, and introduced to the study of world politics by John Ruggie 1975, a small set of literature on the epistemic dimension of world politics has developed on which I base my conceptualization; see Adler and Haas 1992; Ruggie 1993; and Legro 2000. 
a particular paradigm, ${ }^{23}$ the social actors we study rely on a lens to make the world intelligible to themselves. Social Darwinism is an appalling but illustrative example: it is the lens through which (Neo-) Nazis look at the world. The episteme is composed of racial categories (ontological dimension) and their ranking in terms of worthiness, success, and potential (causal dimension). Based on these fundamental and taken-for-granted beliefs, (Neo-) Nazis construct a world that revolves around racial supremacy, racial purity, and violence. ${ }^{24}$

Aristotle and Cicero remind us that agents never use the entire repertoire of ideas to reason about a certain issue. They pick those that help them to make a particular issue intelligible to themselves. ${ }^{25}$ U.S. discourse on war and peace, for example, contains a plethora of ideas to reason about war initiation. The identity narrative alone tells many stories about loss, sacrifice, heroism, cowardice, liberation, suffering, defeat, and victory about Self and Other. Challenged by the question of whether or not to go to war against Iraq, the Bush administration did not invoke the entire identity narrative. Given the many different and partly contradictory clues that the narrative provides, this would have made reaching a conclusion impossible. Instead, the administration clung predominantly to one aspect of the identity narrative - the appeasement of Adolf Hitler at Munich in 1938- to make sense of the course of action to be taken against Saddam Hussein. Following a central insight from argumentation theory, I refer to such an idea that agents pick from the repertoire of commonplaces to reason about a particular issue as topos. ${ }^{26}$

Agents connect topoi to their advocated ideas in various ways. Borrowing from Crawford, this study distinguishes three modes of reasoning: abstraction, comparison, and appropriateness. ${ }^{27}$ Abstraction is a form of logical reasoning. Inferences are made based on general knowledge about cause-effect relationships. The most thoroughly studied kind of abstract reasoning is the syllogism. In its simplest form, it consists of two premises and a conclusion. The major premise contains a desired goal. The minor premise consists of a cause-effect relationship. The conclusion infers the means to achieve the aim from the cause-effect relationship. ${ }^{28}$ The Roman maxim of qui desiderat pacem praeparet bellum, for example, is the conclusion of

23. Kuhn 1962.

24. Note that the episteme, at least if defined in this way, is not an all-encompassing background. It is not the same as the repertoire. Along with the identity narrative and already-selected norms, the episteme is only one ingredient of the repertoire. Yet the episteme is a particularly salient one because it delineates the imaginable. This includes, inter alia, the construction of the identity narrative. For those early twentieth-century reinventors of German identity, for example, who looked at the world through a Social Darwinist lens, a European German identity was inconceivable. Instead, the lens made the most racist identity construction that has ever been embraced by a nation a fully intelligible and therefore possible representation of the nation. For the nexus of background knowledge and identity, see Smith 1979; Cruz 2000; and Kornprobst 2005.

25. See Aristotle 1995; Cicero 1976 and 2003. Cicero translates topos literally with the Latin locus.

26. Topos is usually translated with commonplace. Yet I use the Greek term to emphasize that there is a plethora of commonplaces but agents pick only a few of them-here labeled topoi-to make a particular issue intelligible to themselves. On reasoning and topoi, see also Kratochwil 1989.

27. Crawford 2002, 16-18.

28. Ibid., 28. 
Repertoire of commonplaces: episteme, identity, norms
Construction of link through three modes of reasoning:

- abstraction

- comparison

- appropriateness
Advocated normative idea

FIGURE 1. Reasoning about normative ideas

a syllogism. I want peace (major premise). Only one's military strength prevents one's opponents from breaking the peace (minor premise). Thus, peace can only be achieved by preparing for war (conclusion). ${ }^{29}$

Comparisons equate a phenomenon that is already authoritatively interpreted with something that is new and requires interpretation. There are two basic types of comparisons: historical analogies and metaphors. The two are often difficult to distinguish. Munich, for example, already referred to above, is both a powerful metaphor and historical analogy in world politics. Since the failure of the Munich Conference to appease Hitler, Munich has become a shorthand for the failure of appeasement and the need to stop an aggressor before it is too late.

Appropriateness as reasoning involves relating the advocated idea to existing norms. This may be done in a more or less elaborate manner. Advocates may simply link an idea to an already-internalized norm. Additionally, they may also invoke a string of topoi that justifies the already-institutionalized norm to the advocated idea. Episteme, identity narrative, or other established norms may be among these topoi. The reasoning underpinning Germany's opposition to invading Iraq, for example, revolved around the ius ad bellum as codified in the United Nations Charter. States may only resort to war as a last resort and as an act of defense. These norms are embedded in the identity narrative. Germany's breaches of the laws of war in World War II, in particular, were invoked as a key lesson not to break norms pertaining to war.

Figure 1 summarizes the process of reasoning about normative ideas. Actors employ those topoi from the repertoire of commonplaces that enable them to make sense of a particular issue, and they construct a link between these topoi and the advocated idea. The construction of the link proceeds through three modes of reasoning: abstraction, comparison, and appropriateness.

Building on this conceptual work, the following three sections outline three idealtypical stages of norm selection. I contend that the repertoire of commonplaces provides clues for the formation of an advocacy (innovative argumentation). Inquir-

29. By formal logical standards, this syllogism is imperfect. The major premise ought to categorize rather than express a desire. Yet I follow Crawford because I am concerned with practical reasoning and not with how scholars think the actors they study ought to reason. 
ing into the question of what linkages between what topoi are persuasive to an audience, I identify the properties of a successful argument (persuasive argumentation). Finally, scrutinizing the salience of the repertoire for bargaining processes, I theorize on the conditions under which opponents are swayed by what is to them an unconvincing argument (compromise).

\section{The Formation of Advocacy: Innovative Argumentation}

What makes actors engage in an advocacy for a new normative idea in the first place? I hypothesize that innovative argumentation is made possible by a change in the environment in which agents are embedded. ${ }^{30}$ Two aspects of the environment provide the impetus for a new argumentation: a revolutionary event and a changing repertoire of commonplaces.

Both aspects share an important similarity: they turn the world upside down for agents. This challenges them to abandon old orthodoxies and search for alternatives. Revolutionary events may be appreciated, such as a technological breakthrough, victory in war, or spectacular economic success. Yet they may also be shocking, such as a natural disaster, war, ethnic cleansing, or genocide. Such an event constitutes a "cognitive punch." ${ }^{31}$ It makes clear that the old ways of doing things have become obsolete and have to be replaced by something new. A shifting repertoire replaces old tools for making the world intelligible with new ones. Thus, actors come to reason about the world differently. ${ }^{32}$

There are four possible configurations of a revolutionary event and a changing repertoire. First, if they occur at the same time or follow one another in a short time sequence, the environment is most conducive for agents to initiate an advocacy for a new normative idea. In this case, the revolutionary event challenges actors to embark on new ways of doing things, and the changing repertoire provides them with new clues for doing so. ${ }^{33}$ Second, the propensity of the environ-

30. Human creativity eludes the more or less elegant models that students of human practices attempt to develop. Yet this creativity is made possible by the environment in which human beings are embedded. This allows us at least to theorize on how a particular environment gives rise to a range of possible practices.

31. Adler 1991, 55.

32. The emphasis on the shifting repertoire explains why the first stage of the norm selection mechanism is labeled innovative argumentation. The advocated idea may be an old one. Yet the shifting repertoire requires agents to employ new topoi and construct new linkages between the topoi and the advocated idea. In this sense, the argumentation is innovative.

33. I seek to explain how actors construct a link between an evolving repertoire and a normative idea. I systematically inquire only into the process through which an idea becomes selected as a norm and, thus, becomes an ingredient of the repertoire. The explanation of more profound changes in the repertoire is outside the scope of my study. The significance of revolutionary events is well established in the literature; see Odell 1982; Hall 1986; Adler 1991; and Toulmin 1990. Note that such an event may or may not trigger far-reaching ideational change (in my conceptual language, a shifting repertoire). World War II, for instance, caused a profound ideational change in Europe. World War I, by contrast, did not. For an overview of different routes of ideational change, see Campbell 2004, 62-89. 
TABLE 1. Environments conducive to new arguments about normative ideas

\begin{tabular}{lll}
\hline & Change of repertoire & $\begin{array}{c}\text { No change of } \\
\text { repertoire }\end{array}$ \\
\hline $\begin{array}{l}\text { Revolutionary event } \\
\text { No revolutionary event }\end{array}$ & High & Medium low \\
\hline
\end{tabular}

ment to facilitate the development of a new argument is medium high if the repertoire changes but no revolutionary event occurs. The changing repertoire still enables actors to see the world in a different light, but there is no "cognitive punch" that makes it obvious to actors that what is established has to change. Third, the propensity for a new argument is medium low if there is a "cognitive punch" but no significant change in the repertoire. Agents may feel the need for change, but the environment does not give them new clues about the directions of this change. Finally, the environment is least conducive for change if there is neither a "cognitive punch" nor a significant change in the repertoire of commonplaces. Not only are there no novel clues for how to change something; there is not even a trigger that makes change a necessity in the view of the agents. Table 1 provides an overview of the extent to which different environments facilitate the occurrence of innovative argumentation.

\section{Power of Argument I: Persuasive Argumentation}

Innovative argumentations are initiated frequently, but only a few of them succeed in persuading a broader audience. What makes an advocacy persuasive? Based on the process of reasoning outlined above, my explanatory strategy for this question is twofold. First, I identify the topoi that make for compelling abstract, comparative, and appropriateness reasoning. Some ideas taken from the repertoire of commonplaces make for a more convincing argument than others. Second, I inquire into the opportunities that the support for topoi offers to advocates to assure the audience of their credibility.

This translates into four conditions that facilitate persuasive argumentation. First, arguments that invoke a fit between an advocated normative idea, the dominant episteme, and a nation's widely shared longing for the future facilitate persuasive argumentation. This proposition pertains to abstract reasoning. The conclusion of a syllogism presupposes a goal (major premise) and a cause-effect relationship (minor premise). A nation's widely shared longing for the future is a powerful topos for identifying the goal. The identity narrative sketches paths towards the nation's longing. Nations tend to project the achievement of their most important ideals into the future. In this way, nations are often incomplete by their own judg- 
ment. ${ }^{34}$ The identity narrative also contains cause-effect relationships. The episteme, however, provides a more compelling topos for the minor premise of the syllogism, because the cause-effect relationship of the dominant episteme is situated at a deeper level of the web of taken-for-granted meaning.

Second, arguments that assert a match between widely accepted key events of the identity narrative, the dominant episteme, and the normative idea make persuasive argumentation more likely. This kind of argumentative power stems from the salience of comparative reasoning. Nations interpret their identity narrative through the lens of the episteme. This lens makes actors emphasize certain key events of the identity narrative and predisposes them to make sense of these events in a particular way. Serving as analogies, key events make for powerful topoi, especially if the taken-for-granted lens through which actors look at these eventsthat is, the episteme-is also explicitly invoked as a topos.

Third, arguments that postulate a link between identity-constituting norms, their justification by the dominant episteme and/or key events of the identity narrative, and the advocated idea facilitate persuasive argumentation. As outlined in the previous section, appropriateness reasoning may be underwritten by the justification of an institutionalized norm. A strong justification may revolve around the dominant episteme or key events of the identity narrative or both. Employing such a justification is expected to make for a more compelling argument than appropriateness reasoning that merely invokes an already-institutionalized norm.

Fourth, advocates who have established a reputation with the audience of having persistently supported the topoi of their advocacy not only during the pursuit of this advocacy but also outside of it make persuasive argumentation more likely. Endorsing the topoi not only for a particular advocacy, but having endorsed them beyond it, lends credibility to communicators. It assures the audience that the speakers have not chosen the topoi of the advocacy for opportunistic reasons but because they actually believe in them. ${ }^{35}$

\section{Power of Argument II: Compromise}

If the power of an argument were confined to persuasion, norm selection through argumentation would be a rare phenomenon. It is very unlikely that an argument persuades everyone. Yet the power of an argument is not confined to persuasion. I contend that an advocacy that succeeds in establishing a new majority view puts pressure on recalcitrant actors to comply.

Research on public opinion suggests that an argument, once it has become widely accepted, puts pressure on nonpersuaded actors to conform. ${ }^{36}$ Focusing on norm selection, Finnemore and Sikkink contend that an advocacy that succeeded in per-

34. Meier 1999.

35. For the link between perceived sincerity and credibility, see Eagly, Wood, and Chaiken 1978.

36. Nölle-Neumann 1980. 
suading a critical number of actors puts pressure on recalcitrant actors to rethink their position. This makes them amenable to be swayed into norm compliance by "material sanctions and incentives" offered to them. ${ }^{37}$ What this really suggests is that the pressure of the newly established majority view makes recalcitrant actors sit down at the bargaining table. This contention begs two questions. First, when are actors prepared to sit down at the bargaining table? Do recalcitrant actors yield to the pressure of a successful advocacy independently of their beliefs that made them initially oppose the advocacy? Second, what happens at the bargaining table? What bargaining situation, with what implications for the bargaining outcome, does a successful advocacy create?

Successful argumentation only makes willing to bargain those recalcitrant actors whose repertoire of commonplaces contains the topoi that the advocates invoke in their argumentation. There are two levels of disagreement with an argument: the topoi employed by an advocate may be part of a recalcitrant actor's repertoire of commonplaces. The rift between arguments, however, may cut much deeper. The topoi picked by the advocate may not be part of the counteradvocate's repertoire of commonplaces. In the latter case, the recalcitrant actor refuses to bargain, even if this entails significant costs. Reaching an agreement with the advocate would require the unconvinced actor to violate his or her deepest-held beliefs. If the topoi invoked by the advocate are also part of the recalcitrant actor's repertoire, by contrast, bargaining becomes possible.

What happens once advocates and counteradvocates sharing the advocacy's topoi sit down at the bargaining table? The occurrence of the persuasive argumentation stage of the norm selection mechanism makes clear who is eager to reach an agreement. ${ }^{38}$ The recalcitrant actors are desperate to overcome the costs resulting from their opposition. They seek a way out. Political parties, for example, are likely to act in such a way as to avoid being punished at the polls for defending what has become an unpopular stance. From this eagerness, it follows that the focal pointthat is, the outcome with the highest expected utility that each actor, locked into a game with the other, can achieve-and with it the likely outcome of the bargaining process, is much more closely situated at the position of the successful advocates than at the stance originally embraced by the recalcitrant actors. I refer to such a bargaining success, triggered by the power of an argument, as compromise.

\section{Analyzing Irish Irredentism}

The 1921 Anglo-Irish Treaty established the Irish Free State. The Unionists of Northern Ireland seized upon the opportunity offered by the treaty and opted out

37. Finnemore and Sikkink 1998, 902.

38. Note that this is only one among several possible conceptualizations of a compromise. A newly established majority view provides a weaker impetus to compromise on one's position than, say, an imminent threat of physical force. I am only concerned with the former. 
of the Free State. In the South, the treaty triggered a civil war between those Nationalists in favor of, and those against, signing it. ${ }^{39}$ A party emerging from the latter group, Fianna Fáil, has become the South's most powerful political force. While in power in 1937, it wrote a new Constitution for the Republic of Ireland. In Articles 2 and 3, the Republic codified its irredentist claim to Northern Ireland. In 1998, the Republic renounced its territorial claim in the Good Friday Agreement. This was more than a mere policy change: irredentism had been an article of faith in the Republic until the mid-1980s. The old orthodoxy was replaced in the mid1990s by the widespread normative belief that states ought not to claim territory from other states. Whereas advocates against irredentism were branded traitors in the past, the few remaining opponents arguing against the territorial status quo have been subject to harsh criticism in recent years. Irredentism, once a sacrosanct identity-constituting norm, has been replaced by the territorial status quo norm. The referendum on the Constitutional changes was carried by an overwhelming majority. And even though many provisions of the Good Friday Agreement from which the Republic hoped to benefit failed to be implemented in the following years, no new irredentist debate ensued. The territorial status quo norm assumed a "taken-for-granted quality" in the latter half of the 1990s. It was "no longer a matter of broad public debate," which is the indicator for norm selection that Finnemore and Sikkink use in their research. ${ }^{40}$ What explains this normative change?

The Republic's selection of the territorial status quo norm is well suited for probing the plausibility of the three-stage generative mechanism because, at least at first glance, theories focusing on identity encounter difficulties in accounting for this case. At the core of the identity narrative is a story about Self and Other. Decades prior to normative change in Ireland, West Germany, Italy, Yugoslavia, and Greece ceased to consider claiming territory legitimate although they had been entangled in irredentist disputes across the Cold War divide. Latvia and Lithuania came to take the territorial status quo norm for granted only a few years after Moscow, from which they unambiguously demarcated themselves, released them into sovereign statehood. The Republic of Ireland, by contrast, selected the territorial status quo norm more than half a century after London had granted its independence and a quarter of a century after the Republic and Britain had become partners in the European unification process. ${ }^{41}$

39. I use these labels as they appear in Irish discourse: Nationalists share the ideal of a unified Ireland, whereas Unionists wish to remain a part of the United Kingdom. The overwhelming majority of the Republic's populace and a sizeable minority in the North are Nationalists. The majority in the North are Unionists.

40. Finnemore and Sikkink 1998, 895.

41. This makes Irish irredentism a difficult case for a plausibility probe, but, of course, not a crucial case for testing the theory. The theoretical framework contains several novel elements. Before putting it to a more rigorous and elaborate empirical test, the plausibility probe helps to establish whether such a rigorous test is warranted or whether the theoretical framework has to be revised and probed further prior to such a comprehensive test. 
My argumentation analysis proceeds in two major steps. The empirical examination starts with a thick description of the evolution of the repertoire of commonplaces. This involves tracing the evolution of, and contestation about, epistemes, identity narratives, and already-internalized norms. This step of the empirical analysis recreates the toolbox that enables actors to reason and shows which elements of the repertoire are dominant and which are at the margins.

Next, I trace the generative process through which the norm was selected. This includes a number of tasks. First, I inquire into the salience of the revolutionary event and, building on the previous thick description, inquire into the significance of a shifting repertoire for innovative argumentation. Second, I examine whether the advocates link the topoi to the advocated idea and whether they have established a reputation for supporting these topoi in the manner suggested by the propositions on persuasive argumentation. Third, I use the diffusion and the congruence tests in order to identify persuasive argumentation. The diffusion test focuses on the spread of the intersubjective fit between repertoire and normative idea. If a particular argument, identified by the topoi and the modes of reasoning employed, spreads from one communicator to another, it can be inferred from this that the former persuaded the latter through his or her argument. The reproduction of an argument, therefore, serves as an indicator for persuasion. The congruence test, used when data-such as public opinion surveys-do not allow for the diffusion test, is slightly less demanding. If (1) an audience comes to accept a normative idea, (2) the topoi picked by the advocates are part of the audience's repertoire of commonplaces, and (3) the audience comes to agree with the advocates' argumentation without rewards and punishments being offered, I infer from this the occurrence of persuasive argumentation. Fourth, I use a sequencing test as an indicator for a compromise. At $t_{1}$ some players advocate to select the idea as a norm whereas others argue against it; the former and the latter do not share the same repertoire of commonplaces or, if they do, they disagree about the linkage between the repertoire of commonplaces and the normative idea. Between $t_{1}$ and $t_{2}$, the costs for opposing the normative idea are mounting. At $t_{2}$ the opponents receive a concession by the domestic advocates and/or in the international arena that makes the normative idea, given the opponent's repertoire of commonplaces, less objectionable. At $t_{3}$ the opponents comply with the norm selection but they do not advocate a fit between the norm and the repertoire of commonplaces. Fifth, I discuss alternative explanations.

Throughout my analysis, I rely on six clusters of sources pertaining to debates about the Irish Question from 1921 to 2000: (1) speeches and writings and Irish Taoisigh (prime ministers); (2) Parliamentary debates; ${ }^{42}$ (3) reactions to these debates in major newspapers; ${ }^{43}$ (4) opinion polls; (5) fine arts, plays, and films as

42. I focused on debates in the Dáil Éireann, which is the lower chamber of Parliament, comparable to the House of Commons in Britain. I selected those debates that dealt with general principles of foreign policy and with Northern Ireland.

43. I analyzed the Republic's three national newspapers: Irish Independent, Irish Press, and Irish Times. I examined the reactions to the selected Dáil debates in the two editions following each debate. 
well as fictional literature; and (6) elite interviews. The following section traces the evolution of the repertoire of commonplaces. The three sections thereafterinnovative argumentation, persuasive argumentation, and compromise-discuss how actors related the evolving repertoire to the territorial status quo norm.

\section{The Evolving Repertoire of Commonplaces}

How did the repertoire of commonplaces on which actors could draw to make sense of the Irish Question evolve over time? In the beginning, there was orthodoxy. Fichte's writings are based on four fundamental beliefs about what nations are and what makes them survive. ${ }^{44}$ They constituted the episteme that underpinned the construction of national identity in much of Europe from the midnighteenth to the mid-twentieth century, and Ireland was no exception. The four key beliefs are ubiquitous in the speeches and writings of the three most influential early twentieth-century reinventors of Irishness (Eamon de Valera, William Butler Yeats, and Douglas Hyde): nations are ancient; nations are homogenous; the borders between nations are unambiguous; and the uniqueness of each nation requires a unique form of polity for every nation and autonomy from other nations. ${ }^{45}$ Given the centuries of British colonization and suppression, maintaining uniqueness was equated with fighting off British colonial rule and preventing the recolonization of Ireland by Britain or another major power. Due to this fourth element, this episteme may be labeled a colonial episteme.

The four axioms confined the imaginative space of the reinventors of the Irish nation to an authentic Self that was fundamentally different from the outside world. The dominant Celtic and Catholic representation of Irishness postulated an authentic Self that was exclusive in two ways. First, early twentieth-century nationbuilders sought sharp demarcation from other nations, in particular Britain. Intermingling with other nations was seen as a threat to the authentic Self. ${ }^{46} \mathrm{Sec}$ ond, the dream of the authentic Self did not leave room for those who did not share this vision. Among these were the Unionists of the North. Resolute action would have to be taken against those aligning themselves with Britain: in the words of an influential Dáil deputy, Unionists would have to be "cured of the mental aberration that instigates them to look outside their own country for leadership. ${ }^{47}$ Under no circumstances would the Irish nation accommodate Unionist aspirations.

The dominance of the colonial episteme markedly declined from the 1960s onward. At the same time, an alternative episteme gained influence: an interpreta-

44. Fichte 1978.

45. See De Valera 1980a and 1980b; Yeats 1990; and Hyde 1986.

46. Fanning 1990, 9-10.

47. O’Higgins 1948, col. 1517. 
tion of the Idea of Europe. According to the Idea, rigid borders between Us and Them within and between Europe's nations had caused a series of disasters. Only replacing Europe's splintering into nation-states with cooperation and integration as well as the acknowledgement of the plurality of nations would make it possible to achieve a lasting peace. In the 1940s and 1950s, only a small group of actors embraced the Idea of Europe. ${ }^{48}$ Throughout the Republic's process of applying to the European Economic Community (EEC) in the 1960s, however, the Idea of Europe gained increasing support among elites. More and more Dáil deputies took the Idea of Europe for granted to make sense of European and Irish politics. ${ }^{49}$ By the 1980s, two of the Republic's three most influential political parties, Fine Gael and Labour, had firmly embraced the Idea of Europe. ${ }^{50}$

The more widespread the communal episteme became, the more beleaguered the exclusive identity became. For those making sense of Irishness through the lens of the Idea of Europe, the postulates of the authentic Self were obsolete and dangerous. From the 1980s onward, the exclusiveness of the authentic Self was increasingly criticized in films and fictional literature. ${ }^{51}$ When in office as Taoiseach in the early 1980s, Garret FitzGerald (Fine Gael) vigorously attempted to make Irishness more inclusive. He wanted to "lead a republican crusade" to replace the authentic Self with the ideal of a pluralistic nation. ${ }^{52}$ At the same time, he advocated for the Republic to fully embrace the European unification process.

Charles Haughey (Fianna Fáil) was FitzGerald's principal political opponent. He continued to make sense of Irishness through the colonial episteme. Seen through this perspective, the "crusade was started by the infidels." 53 The inclusiveness advocated by FitzGerald was an inconceivable and implausible identity construct for those who held onto the colonial episteme. For the same reason, FitzGerald's Europhilia was suspect to Haughey. He was adamant that the Republic would have to stand on its own as much as possible. Haughey, however, was forced to resign in 1991. His successors as chairmen of Fianna Fáil and Taoisigh, Albert Reynolds and Bertie Ahern, fully embraced the Idea of Europe. ${ }^{54}$

With the Idea gaining more and more support and the colonial episteme weakening, inclusive Irishness became dominant. Irishness ought to mean to respect the Nationalist and Unionist traditions of the Irish nation and to seek integrating the Republic with other European nations, including Britain. ${ }^{55}$ The Anglo-Irish Agreement, signed by FitzGerald while in office as Taoiseach in 1985, showed the influence of the new episteme and the new identity: the accord was based on

48. See MacBride 1949; Irish Times, 14 July 1949, 5; and Irish Times, 15 July 1950, 5.

49. See Booth 1959; Cosgrave 1962; Costello 1961; Dillon 1962; and Lemass 1962.

50. Goodman 1996, 200-201.

51. See Quinn 1983; Mac Laverty 1983; and Patterson 1988.

52. FitzGerald quoted in Keogh 1995, 357.

53. FitzGerald quoted in Herz 1989, 58.

54. Their different approach was already visible in the 1980s; see Ahern 1985; and Reynolds 1988.

55. Ivory 1999, 89-90. 
two key principles. First, both sides confirmed that they fully respected Unionist and Nationalist aspirations. The principle of consent was a pillar of the Agreement. Ireland would only be unified if this were the wish of the majorities in North and South. Second, Britain and the Republic agreed that improving the situation in the North would require increasing cross-border cooperation and creating joint institutions. Public support for this route to resolve the Irish Question was impressive: 69 percent of the Republic's electorate was in favor of the treaty although the Republic's most powerful party, Fianna Fáil, campaigned against it. Only 20 percent of the electorate opposed it. ${ }^{56} \mathrm{~A}$ majority expected the treaty to improve relations between the Republic and Northern Ireland, ${ }^{57}$ as well as improve the life of Nationalists and the overall situation in Northern Ireland. ${ }^{58}$

Public opinion data on the European unification process also suggest the evolution towards the Idea of Europe and inclusive nationalism. At a time when Euroskepticism began to plague integration efforts in most European countries, referenda on milestones of the European unification process were carried by impressive margins. Although Fianna Fáil campaigned against the Single European Act in 1986, more than two-thirds of the populace voted in favor of the agreement in 1987. The same majority carried the Maastricht Treaty in $1992 .{ }^{59}$ In a 1991 survey, an equally striking 60 percent expressed a desire to create the United States of Europe. ${ }^{60}$ Considering that the Republic had defined itself by standing apart from Europe and world politics in general for half a century, these public opinion data indicate a major epistemic and identity shift. Simultaneous with the strengthening of inclusive identity, the norm of peaceful resolution of disputes became more entrenched. Calls to resort to war in order to retrieve Northern Ireland, still voiced in the 1970s, became unthinkable in the 1980s. ${ }^{61}$

In short, the repertoire of commonplaces on the Irish Question changed dramatically in the twentieth century. In the 1980s, the Idea of Europe came to dominate the colonial episteme, and more and more actors came to imagine an inclusive variant of Irishness. The following three sections examine how advocates drew

56. MRBI survey, 3-4 February 1986 (MRBI/3420/86); wording: "As you are probably aware, an Agreement was signed between the Irish and the British Governments, regarding Northern Ireland. Do you approve or disapprove of the Irish Government signing this Agreement?"

57. Ibid.; wording: "Do you think that this Agreement will: Promote better relations between Northern Ireland and the Republic of Ireland?"

58. MRBI survey, 19-20 November 1986 (MRBI/3410/85); wording: "Do you think that this Agreement will improve life for the Nationalists/Catholics in Northern Ireland?" MRBI-survey, 3-4 February 1986 (MRBI/3420/86); wording: "Do you think that this Agreement will: Promote better relations between the two communities in Northern Ireland?

59. See 〈http://www.electionsireland.org $\rangle$. Accessed 15 September 2006.

60. IMS survey, 5-7 December 1991 (CMC/mcJ.1S393); wording: "There is a lot of talk these days about European Unification. Would you be in favour or opposed to Ireland becoming part of a federal United States of Europe comparable to the United States of America?"

61. Fianna Fáil's Neil Blaney and Desmond Foley were outspoken advocates of taking the military option at least into consideration. Justin Keating (Labour) did not rule out the use of force either; see Blaney, quoted in Keogh 1995, 305; Foley 1972; and Keating 1971. 
on the shifting repertoire to make sense of the Irish Question and the irredentist claim, trace the process through which particular lines of argumentation persuaded audiences, and inquire into the roles that successful argumentation and a shared repertoire of commonplaces played in winning over recalcitrant actors through a compromise.

\section{Innovative Argumentation}

How did the evolution of the criterion affect the formation of advocacies for the territorial status quo? Initially, such an advocacy was inconceivable. For the early twentieth-century reinventors of Irishness, the irredentist claim to Northern Ireland was an article of faith in the Nationalist credo. Irredentism was an unquestionable norm, supported by all three modes of reasoning. First, putting an end to partition is the most important goal of the Irish nation. Partition is caused by Britain's continuing colonization of Northern Ireland. Thus, the Irish nation owes it to itself to pressure Britain to withdraw from Northern Ireland (abstract reasoning). Second, the final withdrawal of the colonizer from Ireland could only be achieved if the Irish were as determined and uncompromising about unity as they had been in the long fight against British colonialism on the island. The present generation owes it to past generations to continue the struggle (comparative reasoning). ${ }^{62}$ Third, the Irish have the right to national self-determination. This right is denied by Britain (appropriateness reasoning).

It was only in the early 1970 s that this orthodoxy was challenged. The advocacy to recognize the existing border began. It started at the height of what the Irish somehow euphemistically call "The Troubles." Violence between Nationalists and Unionists escalated from 1968 onward. In 1969, the Provisional Irish Republican Army split from the Official Irish Republican Army. It started its terrorist campaign two years later. According to official British statistics, the Troubles left almost 2,500 people dead and injured about 27,000 people between 1971 and 1986. Civilian deaths accounted for half of the casualties and two-thirds of the injured. ${ }^{63}$ The key event for Nationalists was "Bloody Sunday" in 1972. British troops opened fire on the participants of a civil rights march in Derry and killed thirteen of them.

The Troubles were a shocking series of events that prompted a number of actors to radically rethink diagnosis and cure of the Irish Question. The repertoire of commonplaces, which had started to change in the 1960s, provided new clues for this endeavor to those actors who embraced its novel dimensions. The two key advocates were Garret FitzGerald and Conor Cruise O'Brien. ${ }^{64}$ Being influential 
journalists and politicians as well as protagonists of the Idea of Europe and a more inclusive identity narrative, they had already established a reputation with their audience for fully endorsing those new clues of the repertoire that they employed as topoi for their argumentation for the idea of a territorial status quo norm. ${ }^{65}$

They linked the shifting repertoire to this normative idea through comparative reasoning. The topoi of this reasoning were the Idea of Europe and particular interpretations of partition and the Troubles. Seen through the Idea of Europe, a fundamental lesson had to be learned from Irish history: exclusion breeds violence. In the twentieth century, the majority (Nationalists) had tried to impose its conception of Irishness onto the minority (Unionists). As a consequence, the minority felt threatened. Out of legitimate fear, it opted out of Ireland and was determined to hold onto its autonomy from Dublin by any means possible, including a de facto civil war in the North. Taking this historical lesson seriously meant redefining Irishness in a more inclusive manner and dropping the irredentist claim. It would assure Unionists that they would not be forced into the Republic and that the Republic, in a nonsectarian manner, would respect their tradition and their wishes. $^{66}$

Additionally, FitzGerald also employed abstract reasoning, composed of the topoi of longing for unity and the Idea of Europe. The major premise of the syllogism was the desire for unity on the island of Ireland. The minor premise was that the gradual increase in cooperation and integration across state borders takes away the divisive nature of these borders and may ultimately even make the borders obsolete. FitzGerald inferred from this that a chance for reunification could only be kept alive if North and South embarked on a cooperation and integration scheme modeled after the European unification process. The irredentist claim was a stumbling block making such a process impossible to initiate. Borders would first have to be recognized in order to be overcome through a historical process.

The advocates, especially FitzGerald, were initially very cautious in formulating this reasoning in public. FitzGerald's advocacy started in 1969 within his own party (Fine Gael) and refrained from making the withdrawal of the territorial claim explicit at that point in time. Only when he realized that the continuing violence in Northern Ireland made it possible to think aloud of radical alternatives to the Republic's stance on the Irish Question, did he explicitly call for forgoing irredentism within and outside of Fine Gael. ${ }^{67}$ By the mid-1970s, FitzGerald and O'Brien succeeded in establishing an advocacy network among a small group of Dáil deputies. $^{68}$

65. See Mair 1987; and Keogh 1995, 285, 356-57. See also the previous section on the evolution of the repertoire of commonplaces. This reputation extended increasingly to the political parties of FitzGerald and O'Brien, that is, Fine Gael and Labour, respectively; see Ivory 1999.

66. See FitzGerald 1972 and 1991; and O’Brien 1972 and 1999.

67. FitzGerald 1991, 222-23.

68. See, in particular, O'Leary 1972; and Carter 1974. 
In sum, advocates initiated a new advocacy in what was hypothesized to be a highly conducive environment for innovative argumentation. The Troubles were the revolutionary event that made it clear to actors that something had to change, and the shifting repertoire of commonplaces enabled those actors who embraced the novel dimensions to imagine new directions for dealing with the Irish Question.

\section{Persuasive Argumentation}

The innovative argumentation included a number of elements that were hypothesized to make an argumentation successful. For one, the advocates had established a reputation as supporters of the topoi of their argumentation even outside of the advocacy. This applies to Fine Gael and Labour at large and especially to FitzGerald and O'Brien. Furthermore, using key events of the identity narrativeincluding the longing for unity - and the episteme as topoi, the advocates employed abstract and comparative reasoning. Other hypothesized elements, however, were missing prior to the mid-1980s. The topoi that the advocates employed had not yet become widely shared. They had not become part of the dominant repertoire of commonplaces. This seriously undermined their argumentation's persuasive power throughout the 1970 s. Many vilified the advocates as traitors. ${ }^{69}$

The argumentation changed only in nuances over the decades. The abstract and comparative modes of reasoning continued to dominate the advocacy. ${ }^{70}$ The appropriateness mode, added from the late 1980s onward, remained less pronounced. Some advocates of Constitutional change emphasized the norm of peaceful resolution of disputes and used it as a marker to distance themselves from the IRA's aggressive nationalism and violent pursuit of Irish unity. ${ }^{71}$

Although the argumentation remained virtually unchanged, it became much more successful from the mid-1980s onward. More and more actors became persuaded of the argumentation. By the early 1990s, Fianna Fáil was the only major political party to uphold the irredentist claim. Among the three major newspapers, only the Irish Press defended Fianna Fáil's stance. ${ }^{72}$ The available public opinion data show that the argumentation for Constitutional change began to resonate with the public in the early 1990s. Table 2 shows the results of opinion polls on changing Articles 2 and 3 from a territorial claim to an aspiration for unity.

69. See Irish Press, 10 March 1971, 10; and Irish Press, 5 February 1972, 10. In the Dáil, Neil Blaney was the most outspoken critic of recognition; see Blaney 1974.

70. With regard to the central place of the European unification process in his thinking, John Bruton was the political heir of FitzGerald; see Bruton 1990 and 1993. Yet others argued in a similar vein. See, for example, De Rossa 1993.

71. See Ross 1988; Norris 1988; De Rossa 1993; Harney 1993; and McDowell 1993.

72. The Irish Independent and the Irish Times were very critical of the Republic's claim of legal right to Northern Ireland: Irish Independent, 20 November 1985, 12; Irish Independent, 23 November 1985, 8; and Irish Times, 22 November 1985, 9. 
TABLE 2. Public opinion on amending

Articles 2 and 3

\begin{tabular}{lllll}
\hline & 1981 & 1992 & 1993 & 1995 \\
\hline Support & $35 \%$ & $41 \%$ & $39 \%$ & $60 \%$ \\
Oppose & $46 \%$ & $39 \%$ & $32 \%$ & $20 \%$ \\
Don't know & $17 \%$ & $20 \%$ & $29 \%$ & $20 \%$ \\
\hline
\end{tabular}

In 1981, almost half of the populace was still opposed to amending the Constitution. ${ }^{73}$ In 1992, there was a majority in favor of amendment for the first time; 41 percent wished the territorial claim to be replaced by an aspiration for unity, whereas 39 percent rejected this option. ${ }^{74}$ In 1993, the margin between those in favor of amendment and those against increased to 7 percent; 39 percent preferred amendment while 32 percent were opposed. ${ }^{75}$ By 1995, the support for amendment had increased by more than 20 percent; 60 percent opted for Articles 2 and 3 expressing an aspiration, and only 20 percent wanted to retain the de jure claim. ${ }^{76}$ This remarkable shift in public opinion occurred prior to the tangible benefits offered to the Republic and the Nationalists of Northern Ireland in the Good Friday Agreement.

What made this extraordinary success of the advocacy possible? By the mid1980 s, the element that was hypothesized to facilitate persuasive argumentation but had been absent during the 1970s was no longer missing. In the 1970s, the advocates' argumentation had linked the idea for a territorial status quo norm to the episteme and the nation's longing for the future (abstract reasoning) and it had connected the idea to key events of the identity narrative and the episteme (comparative reasoning). As powerful as this argumentation had been for the few actors

73. IMS survey, 14-15 October 1981 (j.8041); wording: "The Irish Constitution claims jurisdiction over the whole of this island, North and South. It has been suggested that this might be changed to drop the claim to jurisdiction over Northern Ireland. Would you approve or disapprove of such a change?"

74. MRBI survey, 24-25 September 1992 (MRBI/4080/92); wording: "Articles $2 \& 3$ of the Constitution which claim jurisdiction over all of Ireland are being discussed by the Irish and British Governments and the Northern Parties. Do you think the claim in Articles $2 \& 3$ should be retained, or should the claim be changed to an aspiration?"

75. IMS survey, 1-8 April 1993 (CMC/1d/j.3S125); wording: "It has been suggested that Articles 2 and 3 of our Constitution should be amended to confirm our acceptance that there will be no change to the existing status of Northern Ireland except by peaceful means and with the consent of the majority of Northern Ireland. Do you think Articles 2 and 3 should be left as they are, or do you think they should be amended as outlined?"

76. MRBI survey, 20-22 May 1995 (MRBI/4290/95); wording: "Should or should not the following provisions be put into a new or amended Constitution? Change of Articles 2 and 3 from a territorial claim on NI to an aspiration of unity?" 
who shared the advocates' episteme and identity narrative, its appeal to a broader audience had remained limited. Only when the shift of the repertoire was completed and the episteme and the identity that the advocates took for granted became dominant in Irish discourse did their argumentation resonate with a broader audience. Persuaders and persuadees came to share a lifeworld, which made meaningful communication and persuasion possible.

\section{Compromise}

As successful as the advocacy had been, a number of recalcitrant actors remained. Some of them had come to embrace the Idea of Europe, inclusive nationalism, and its constituting norms. Although they shared the advocates' repertoire of commonplaces, however, they remained unconvinced of the linkages that the advocates proposed between irredentism and the topoi that the advocates picked from the repertoire. This is why Fianna Fáil objected to renouncing irredentism. Other actors, such as Independent Fianna Fáil, did not share the newly dominant repertoire. They held onto the colonial episteme and exclusive nationalism.

Yet the successful argumentation inflicted heavy costs on the recalcitrant actors. In 1993, the Irish Press was swayed by public pressure. Asserting that there was "a sense of urgency to match the public mood," 77 the Irish Press stopped its counteradvocacy against recognition, without, however, endorsing the argumentation for recognition. Although Fianna Fáil suffered heavy costs for upholding the irredentist tradition, it did not bend so easily. Before the 1970s, Fianna Fáil majority governments were only occasionally interrupted by coalition governments headed by Fine Gael. From the 1970s onward, however, Fianna Fáil found it increasingly difficult to form a government-even with the help of a coalition partner. The guardian of de Valera's ideals lost the close link to the populace of which de Valera had been so proud precisely because it held onto these ideals, symbolized in many ways by the irredentist claim.

Thanks to its coalition partner, the Progressive Democrats, Fianna Fáil came back to power in 1997. The Fine Gael-led government that had preceded this coalition had made far-reaching promises about the Republic's contribution to the peace process in Northern Ireland. In sharp contrast to previous commitments by Fianna Fáil governments, Fine Gael had announced in 1995 that the Republic would amend its Constitution to clarify that the Unionists of Northern Ireland would not be forced into the Republic. Fine Gael was committed to replacing the claim of legal right with an aspiration for unity. Given Fine Gael's argumentation on the Irish Question, it was not surprising that the party agreed to change the Constitution in the Framework Document. The Progressive Democrats had been persuaded of this 
stance by the early 1990 s. $^{78}$ But what would Fianna Fáil, the senior partner in the new coalition government, do?

Britain and the Unionists of Northern Ireland offered a Council of Ireland in exchange for forgoing irredentism. The Council, composed of delegations from the Republic and Northern Ireland, would discuss matters of relevance to both parts of Ireland. Furthermore, Nationalists in the North would participate in a power-sharing executive. The Taoiseach Bertie Ahern and his foreign minister David Andrews toured the country and tried to convince their party in numerous meetings that the benefits of Council and power-sharing were unattainable without renouncing the claim of legal right to Northern Ireland. ${ }^{79}$

In 1973, Fianna Fáil had still opposed the Sunningdale Communiqué. The agreement had offered similar benefits and demanded a far less explicit assurance to Unionists than the recognition of the territorial status quo. Given the mounting pressure on the party in the late 1990s, however, Ahern and Andrews succeeded in winning the support of Fianna Fáil. In 1998, Ahern signed the Good Friday Agreement. In the accord, the Republic announced that it would hold a referendum on replacing the territorial claim in Articles 2 and 3 with an aspiration. An impressive majority of 94 percent carried the referendum. ${ }^{80}$ The enactment of this article ended the fifty-one-year-old irredentist claim. Despite major setbacks during the implementation process of the accord, the territorial status quo norm has become institutionalized. There is no debate anymore about claiming territory. The norm that states ought not to claim territory from other states has become included in the Republic's repertoire of commonplaces and may be used as a topos in future debates on foreign policy.

\section{Conclusion}

The empirical findings lend evidence to the three-stage norm selection mechanism. First, environmental change made actors embark on an advocacy in favor of the territorial status quo norm. The Troubles were the revolutionary event that made it clear to the advocates that the old ways of doing things had become obsolete and the changing repertoire of commonplaces, in particular the changes from the colonial episteme to the Idea of Europe and from exclusive to inclusive nationalism, provided the clues for what the new should look like. Second, advocates who had established a reputation for persistently supporting the topoi of their advocacy even outside of the advocacy succeeded in persuading large segments of the elites and the public. They did so by linking the advocated idea of a territorial status quo norm to the already-selected norm of peaceful resolution of disputes

78. See O'Malley 1985; and Harney 1993.

79. Interview with David Andrews in Dublin, 29 January 2004.

80. See $\langle$ http://www.electionsireland.org $\rangle$. Accessed 15 September 2006. 
and its almost consensual justification (appropriateness reasoning); by linking it to the Idea of Europe - that is, the dominant episteme - and the nation's longing for unification, which was a key aspect of the dominant identity narrative (abstract reasoning); and by linking it to violence between Nationalists and Unionistsalso an important aspect of the dominant identity narrative-as seen in the light of the European episteme (comparative reasoning). Third, when the costs of opposing the newly established majority view mounted, those recalcitrant actors who shared the advocates' repertoire of commonplaces accepted a compromise with the advocates, even though the compromise clearly favored the advocates' position.

As promising as these results are, there are also a few caveats. The Irish case shows that the three stages are only ideal-types. As useful as the three stages are as a heuristic device, they are not real-types. The decision by the Irish Press to cease its support for irredentism, for example, is not adequately captured by the compromise. The newspaper was swayed by public pressure without receiving a concession. Furthermore, the plausibility probe was merely a preliminary test. Only a more comprehensive scrutiny of a number of cases can provide compelling answers to questions such as the following: Do some modes of reasoning make for a more compelling argument than others? Comparative reasoning, especially if aimed at persuading the public, may be more persuasive than, say, abstract reasoning. Alternatively, a combination of all three modes of reasoning may make for a very compelling argument. Do some shifting aspects of a repertoire of commonplaces provide a stronger impetus for innovative argumentation than others? The Irish case suggests that epistemic change may have especially profound repercussions.

Even without further elaborating on the theoretical framework, however, the three-stage norm selection mechanism provides a more compelling account than alternative explanations. From a realist perspective, the withering away of irredentism was simply a function of the power discrepancy between the Republic and the United Kingdom. Dublin lacked the necessary means to force the United Kingdom into surrendering Northern Ireland. This made the territorial claim futile. This hypothesis cannot explain, however, why Dublin claimed Northern Ireland for more than fifty years before withdrawing the claim. The power discrepancy never changed significantly. ${ }^{81}$

Rational choice provides some important insights into the Republic's domestic politics. Pressure by the electorate influenced recalcitrant elites. ${ }^{82}$ Moreover, bargaining theory helps to explain why Fianna Fáil, once under pressure by public opinion, came to end its counteradvocacy. ${ }^{83}$ The picture, however, remains incomplete in three ways. First, according to rational choice theory, all political actors

81. Skelly applies realist insights on major power relations to the study of Irish foreign policy; see Skelly 1997.

82. This link is well developed in Dai 2005.

83. For an account of Irish foreign policy through a rational choice perspective, see O'Halpin 1999. 
incurring costs from opposing the newly established majority view should have renounced their irredentist stance. Actors such as Independent Fianna Fáil, however, refused to bend. Second, rationalist approaches cannot explain why actors, despite the costs this initially inflicted on them, started an advocacy for overcoming irredentism. At the beginning, the majority of social actors and the public were outraged about the advocates' rejection of Articles 2 and 3 of the Constitution. Third, it is puzzling from a rational choice perspective that more and more social actors as well as the public became opposed to irredentism years before the Good Friday Agreement offered tangible benefits to the Republic and the Nationalists of Northern Ireland. In additon to these three problems, there is no evidence that Brussels linked financial assistance to the withdrawal of the irredentist claim. After the Good Friday Agreement, there has even been a slight decrease in structural and cohesion funds because of the Republic's continuing economic growth. ${ }^{84}$

Existing constructivist accounts provide an important starting point for analyzing the research puzzle, but they are incomplete. Authors point to the Republic's European worldview ${ }^{85}$ and to the change from exclusive to inclusive nationalism, ${ }^{86}$ and allude to the reconstitution of Irishness by European norms. ${ }^{87}$ Yet the mechanism linking the change in the environment to the selection of the territorial status quo norm is missing. Environmental change did not automatically translate into norm selection. The success of the advocacy lagged years behind the spread of the new repertoire of commonplaces. The advocacy literature helps to explain these links, but also falls short of providing a compelling account: it does not inquire into the origins of an advocacy; it fails to specify the linkages between established ideas and the advocated idea; and it cannot explain how recalcitrant actors were won over although they were never persuaded by the argument.

The results of this study have at least three important implications for international relations theory. First, argumentation matters. The social environment in which actors are embedded does not determine their actions. It is a resource that enables them to reason and to communicate with others. The environment is an impetus for actors to try to persuade others and the social context that offers or denies the possibility of this attempt being successful. Hence, the environment should only be the starting point of our analyses, followed by an exploration of how agents, in their quest to make the world intelligible to themselves, come to assemble different aspects of this environment into what is to them a coherent picture. Second, a particularly profound aspect of this enabling environment is the worldview, which I conceptualized as episteme in this study. It is perhaps no coincidence that the advocacy literature confines itself to what I referred to in this study as appropriateness reasoning. Only taking the episteme seriously makes it possi-

84. National Development Plan 2005. The Republic received €11 billion from 1989 to 1999 and $€ 4$ billion are earmarked for the period from 2000-2006.

85. MacLaughlin 2001.

86. See Girvin 1994; and Howe 2000.

87. See Harris 2001; and MacLaughlin 2001. 
ble to inquire into abstract and comparative reasoning as defined in this article. Without the episteme, there is no minor premise of the syllogism and therefore no abstract reasoning; and there is no comparative reasoning because this requires the interpretation of one's history through a paradigmatic perspective. Finally, the logic of consequences and the logic of appropriateness are pervasive aspects of social life. The plausibility of our theoretical frameworks depends, to a considerable extent, on our ability to find a compelling synthesis between these logics of action. Argumentation theory provides interesting leads for this endeavor that go beyond what I suggested in this article: what rational choice defines as rationality is a form of reasoning. But it is not the only one.

\section{References}

Acharya, Amitav. 2004. How Ideas Spread: Whose Norms Matter? Norm Localization and Institutional Change in Asian Regionalism. International Organization 58 (2):239-75.

Adler, Emanuel. 1991. Cognitive Evolution: A Dynamic Approach for the Study of International Relations and Their Progress. In Progress in Postwar International Relations, edited by Emanuel Adler and Beverly Crawford, 128-73. New York: Columbia University Press.

Adler, Emanuel, and Peter Haas. 1992. Conclusion: Epistemic Communities, World Order, and the Creation of a Reflective Research Program. International Organization 46 (1):367-90.

Ahern, Bertie. 1985. Dáil Éireann Debates 361, 20 November, col. 2856-63.

Aristotle. 1995. Rhetorik. Translated by Franz G. Sieveke. Munich, Germany: Wilhelm Fink.

Barnett, Michael. 1999. Culture, Strategy and Foreign Policy Change: Israel's Road to Oslo. European Journal of International Relations 5 (1):5-36.

Berger, Peter, and Thomas Luckmann. 1966. The Social Construction of Reality: A Treatise in the Sociology of Knowledge. New York: Anchor Books.

Bernstein, Steven. 2000. Ideas, Social Structure and the Compromise of Liberal Environmentalism. European Journal of International Relations 6 (4):464-512.

Blaney, Neil. 1974. Dáil Éireann Debates 275, 6 November, col. 1109-10.

Booth, Lionel.1959. Dáil Éireann Debates 176, 7 July, col. 639-44.

Bruton, John. 1990. Dáil Éireann Debates 403, 28 November, col. 471-74. 1993. Dáil Éireann Debates 437, 17 December, col. 1243-56.

Campbell, John. 2004. Institutional Change and Globalization. Princeton, N.J.: Princeton University Press.

Carter, Frank. 1974. Dáil Éireann Debates 275, 6 November, col. 1185.

Checkel, Jeffrey. 2001. Why Comply? Social Learning and European Identity Change. International Organization 55 (3):553-88.

Cicero, Marcus Tullius. 1976. De Oratore. Translated by Harald Merklin. Stuttgart, Germany: Reclam. - 2003. Topica. Translated by Tobias Reinhardt. Oxford, England: Oxford University Press.

Cortell, Andrew P., and James W. Davis. 2005. When Norms Clash: International Norms, Domestic Practices, and Japan's Internalization of the GATT/WTO. Review of International Studies 31 (1):3-25.

Cosgrave, Liam. 1962. Dáil Éireann Debates 194, 5 April, col. 1356-58.

Costello, Declan. 1961. Dáil Éireann Debates 191, 11 July, col. 560-61.

Crawford, Neta. 2002. Argument and Change in World Politics: Ethics, Decolonization, and Humanitarian Intervention. Cambridge: Cambridge University Press.

Cruz, Consuelo. 2000. Identity and Persuasion: How Nations Remember Their Pasts and Make Their Futures. World Politics 52 (3):275-312.

Dai, Xinyuan. 2005. Why Comply? The Domestic Constituency Mechanism. International Organization 59 (2):363-98. 
Day, Alan J. 1992. The Northern Ireland Question. In Border and Territorial Disputes, 3d ed., edited by John B. Allcock, 120-41. Harlow, England: Longman.

De Rossa, Proinsias. 1993. Dáil Éireann Debates 437, 17 December, col. 1286-89.

De Valera, Eamon. 1980a. A Race That Never Ceased to Strive. In Speeches and Statements by Eamon de Valera: 1917-73, edited by Maurice Moynihan, 35-36. Dublin: Gill and Macmillan.

- 1980b. Ireland's Request. In Speeches and Statements by Eamon de Valera: 1917-73, edited by Maurice Moynihan, 36-46. Dublin: Gill and Macmillan.

Dillon, James. 1962. Dáil Éireann Debates 198, 13 December, col. 1354.

Downs, George, David Rocke, and Peter Barsoom. 1996. Is the Good News About Compliance Good News About Cooperation? International Organization 50 (3):379-406.

Eagly, Alice H., Wendy Wood, and Shelly Chaiken. 1978. Causal Inferences About Communicators and Their Effects on Opinion Change. Journal of Personality and Social Psychology 36 (2):424-35.

Fanning, Ronan. 1990. Irish Neutrality. Neutrals in Europe: Ireland, Edited by Bo Huldt and Ari Lejins, 1-24. Stockholm: The Swedish Institute of International Affairs.

Fichte, Johann Gottlieb. 1978. Reden an die deutsche Nation. Hamburg, Germany: Meiner.

Finnemore, Martha, and Kathryn Sikkink. 1998. International Norm Dynamics and Political Change. International Organization 52 (4):887-917.

FitzGerald, Garret. 1972. Towards a New Ireland. London: Charles Knight.

. 1991. All in a Life: Garrett FitzGerald, an Autobiography. Dublin: Gill and Macmillan.

Foley, Desmond. 1972. Dáil Éireann Debates 258, 4 February, col. 1081.

Florini, Ann. 1996. The Evolution of International Norms. International Studies Quarterly 40 (3): 363-89.

Foucault, Michel. 1989a. The Order of Things: An Archaeology of the Human Sciences. New York: Routledge.

- 1989b. The Archaeology of Knowledge. New York: Routledge.

Girvin, Brian. 1994. Constitutional Nationalism and Northern Ireland. In The Northern Ireland Question: Perspectives and Policies, edited by Brian Barton and Patrick J. Roche, 5-52. Aldershot, England: Avebury.

Goffman, Erving. 1974. Frame Analysis: An Essay on the Organization of Experience. New York: Harper \& Row.

Goldstein, Judith, and Robert O. Keohane. 1993. Ideas and Foreign Policy: An Analytical Framework. In Ideas and Foreign Policy: Beliefs, Institutions, and Political Change, edited by Judith Goldstein and Robert O. Keohane, 3-30. Ithaca, N.Y.: Cornell University Press.

Goodman, James. 1996. Nationalism and Transnationalism: The National Conflict in Ireland and European Union Integration. Aldershot, England: Ashgate.

Habermas, Jürgen. 1995a. Theorie des kommunikativen Handelns I: Handlungsrationalität und gesellschaftliche Rationalisierung. Frankfurt am Main, Germany: Suhrkamp.

1995b. Theorie des kommunikativen Handelns II: Zur Kritik der funktionalistischen Vernunft. Frankfurt am Main, Germany: Suhrkamp.

-1998. Faktizität und Geltung: Beiträge zur Diskurstheorie des Rechts und des demokratischen Rechtsstaats. Frankfurt am Main, Germany: Suhrkamp.

Hall, Peter. 1986. Governing the Economy: The Politics of State Intervention in Britain and France. New York: Oxford University Press.

Harney, Mary. 1993. Dáil Éireann Debates 437, 17 December, col. 1259-69.

Harris, Clodagh. 2001. Anglo-Irish Elite Cooperation and the Peace Process: The Impact of the EEC/ EU. Irish Studies in International Affairs 12:203-14.

Herz, Dietmar. 1989. Frieden und Stabilität: Die Nordirland-Politik der Republik Irland 1969-1987. Bochum, Germany: Studienverlag Dr. N. Brockmeyer.

Holzinger, Katharina. 2001. Kommunikationsmodi und Handlungstypen in den Internationalen Beziehungen: Anmerkungen zu einigen irreführenden Dichotomien. Zeitschrift für internationale Beziehungen 8 (2):243-86.

Howe, Stephen. 2000. Ireland and Empire: Colonial Legacies in Irish History and Culture. Oxford, England: Oxford University Press. 
Hyde, Douglas. 1986. On the Necessity of De-Anglicising Ireland. In Douglas Hyde: Language, Lore and Lyrics, edited by Breandán Ó Conaire, 153-70. Dublin: Irish Academic Press.

Ivory, Gareth. 1999. Revisions in Nationalist Discourse Among Irish Political Parties. Irish Political Studies 14 (1):84-103.

Keating, Justin. 1971. Dáil Éireann Debates 252, 3 March, col. 257.

Keck, Margaret, and Kathryn Sikkink. 1998. Activists beyond Borders: Advocacy Networks in International Politics. Ithaca, N.Y.: Cornell University Press.

Keck, Otto. 1995. Rationales kommunikatives Handeln in den internationalen Beziehungen, Zeitschrift für Internationale Beziehungen 2 (1):5-48.

Kelemen, R. Daniel, and Eric C. Sibbitt. 2004. The Globalization of American Law. International Organization 58 (1):103-36.

Keogh, Dermot. 1995. Twentieth-Century Ireland: Nation and State. New York: St. Martin's Press.

Kornprobst, Markus. 2005. Episteme, Nation-Builders and National Identity: The Re-construction of Irishness. Nations and Nationalism 11 (3):403-22.

Kratochwil, Friedrich. 1989. Rules, Norms and Decisions: On the Conditions of Practical and Legal Reasoning in International Relations and Domestic Affairs. Cambridge: Cambridge University Press.

Kuhn, Thomas. 1962. The Structure of Scientific Revolutions. Chicago: University of Chicago Press.

Laffey, Mark, and Jutta Weldes. 1997. Beyond Belief: Ideas and Symbolic Technologies in the Study of International Relations. European Journal of International Relations 3 (2):193-237.

Langlois, Catherine, and Jean-Pierre Langlois. 2004. Provisions for Noncompliance and Treaty Value: A Game Theoretic Perspective. International Studies Quarterly 48 (2):383-408.

Legro, Jeffrey. 2000. Whence American Internationalism. International Organization 54 (2):253-89.

Lehane, Con. 1948. Dáil Éireann Debates 113, 14 December, col. 1515.

Lemass, Noel. 1962. Dáil Éireann Debates 194, 5 April, col. 1370-71.

Luckmann, Thomas. 1991. Die unsichtbare Religion. Frankfurt am Main, Germany: Suhrkamp.

MacBride, Séan. 1949. Dáil Éireann Debates 117, 12 July, col. 695-709.

MacLaughlin, Jim. 2001. Reimagining the Nation-State: The Contested Terrains of Nation-building. London: Pluto.

Mac Laverty, Bernard. 1983. Cal. London: Jonathan Cape.

Mair, Peter. 1987. Breaking the Nationalist Mould. In Beyond the Rhetoric: Politics, the Economy and Social Policy in Ireland, edited by Paul Teague, 81-110. London: Lawrence and Wishart.

March, James, and Johan Olsen. 1989. Rediscovering Institutions: The Organizational Basis of Politics. New York: Free Press.

McDowell, Michael. 1993. Dáil Éireann Debates 437, 17 December, col. 1274-89.

Meier, Charles. 1999. The End of Longing? In The Postwar Transformation of Germany: Democracy, Prosperity, and Nationhood, edited by John S. Brady, Beverly Crawford, and Sarah Elise Wiliarty, 271-85. Ann Arbor: University of Michigan Press.

Müller, Harald. 1994. Internationale Beziehungen als kommunikatives Handeln: Zur Kritik der utilitaristischen Handlungstheorien. Zeitschrift für internationale Beziehungen 1 (1):15-44.

National Development Plan. 2005. Ireland and the E.U. Structural Funds. Available at 〈http:// www.csfinfo.com/htm/overview/structural_funds.htm $\rangle$. Accessed 15 September 2006.

Norris, David. 1988. Seanad Éireann 124, 16 November, col. 935.

Nölle-Neumann, Elisabeth. 1980. Die Schweigespirale: öffentliche Meinung, unsere soziale Haut. Munich, Germany: Piper.

O'Brien, Conor Cruise. 1972. States of Ireland. London: Hutchinson. 1999. Memoir: My Life and Themes. Dublin: Poolbeg.

Odell, John. 1982. U.S. International Monetary Policy: Markets, Power, and Ideas as Sources of Change. Princeton, N.J.: Princeton University Press.

O'Halpin, Eunan. 1999. Defending Ireland: The Irish State and Its Enemies Since 1922. Oxford, England: Oxford University Press.

O’Higgins, Thomas. 1948. Dáil Éireann Debates 113, 14 December, col. 1516-17.

O’Leary, Michael. 1972. Dáil Éireann Debates 260, 18 April, col. 477-93.

O’Malley, Desmond. 1985. Dáil Éireann Debates 361, 21 November, col. 2985-86. 
Patterson, Glenn. 1988. Burning Your Own. London: Chatto \& Windus.

Perelman, Chaïm, and Lucie Olbrechts-Tyteca. 1958. Traité de l'argumentation. Paris: Presses Universitaires de France.

Quinn, Bob (director). 1983. Atlantean. De Facto Films. Ireland.

Reynolds, Albert. 1988. Dáil Éireann Debates 384, 16 November, col. 769.

Risse, Thomas. 2000. 'Let's Argue!': Communicative Action in World Politics. International Organization 54 (1):1-39.

Risse, Thomas, Stephen Ropp, and Kathryn Sikkink, eds. 1999. The Power of Human Rights: International Norms and Domestic Change. Cambridge: Cambridge University Press.

Ross, Shane. 1988. Seanad Éireann 384, 16 November, col. 721.

Ruggie, John. 1975. International Responses to Technology: Concepts and Trends. International Organization 29 (3):557-83.

1993. Territoriality and Beyond: Problematizing Modernity in International Relations. International Organization 47 (1):139-74.

Schimmelfennig, Frank. 2003. The EU, NATO and the Integration of Europe. Cambridge: Cambridge University Press.

Simmons, Beth. 2000. International Law and State Behavior: Commitment and Compliance in International Monetary Affairs. American Political Science Review 94 (4):819-35.

Skelly, Joseph. 1997. Irish Diplomacy at the United Nations, 1945-1965: National Interests and the International Order. Dublin: Irish Academic Press.

Smith, Anthony. 1979. Nationalism in the Twentieth Century. Oxford, England: Martin Robertson.

Somers, Margaret. 1994. The Narrative Constitution of Identity: A Relational and Network Approach. Theory and Society 23 (5):605-49.

Swidler, Ann. 1986. Culture in Action: Symbols and Strategies. American Sociological Review 51 (2):273-86.

Tallberg, Jonas. 2002. Paths to Compliance: Enforcement, Management, and the European Union. International Organization 56 (3):609-43.

Toulmin, Stephen. 1990. Cosmopolis: The Hidden Agenda of Modernity. Chicago: University of Chicago Press.

Wiener, Antje. 2004. Contested Compliance: Interventions on the Normative Structure of World Politics. European Journal of International Relations 10 (2):189-234.

Yeats, William Butler. 1990. A Vision and Related Writings. London: Arena.

Zacher, Mark W. 2001. The Territorial Integrity Norm: International Boundaries and the Use of Force. International Organization 55 (2):215-50. 